Journal of Advanced Research in Fluid Mechanics and Thermal Sciences

\title{
Experimental Investigation of a Split Air Conditioning Using Condensate as Direct Evaporative Cooling
}

\author{
Azridjal Aziz ${ }^{1,}{ }^{*}$, Muhammad Rif'at Syahnan ${ }^{1}$, Afdhal Kurniawan Mainil $^{2}$, Rahmat Iman Mainil ${ }^{1}$ \\ Department of Mechanical Engineering, Faculty of Engineering, Universitas Riau, J. Subrantas km 12.5, Pekanbaru, Indonesia \\ Department of Mechanical Engineering, Faculty of Engineering, Universitas Bengkulu, Jl. WR. Supratman, Kandang Limun, Bengkulu 38371A, \\ Indonesia
}

\section{ARTICLE INFO}

Article history:

Received 14 April 2021

Received in revised form 15 June 2021

Accepted 20 June 2021

Available online 17 August 2021

Keywords:

Air Conditioning system; evaporative cooling; COP

\section{ABSTRACT}

Split air conditioning systems produce reasonable amount of condensate which is usually not utilized and thrown away to the environment. On the other hand, it consumes a lot of energy during operation. The aim of this study is to investigate the improvement of air conditioning systems performance utilizing condensate. A direct evaporative cooling using condensate is incorporated on a 0.74 ton-cooling capacity of split air conditioning to decrease the air temperature before entering the condenser. Performances of the split air conditioning with and without direct evaporative cooling are compared and presented in this paper. The results show that the use of direct evaporative cooling using condensate into the air before passing through the condenser reduces the compressor discharge pressure. The decrease of the condenser pressure led to $4.7 \%$ and $7 \%$ reduction of power consumption for air conditioner without cooling load and air conditioner with $2000 \mathrm{~W}$ cooling load, respectively. The cooling effect and coefficient of performance (COP) increase with the decrease of compressor power. The use of direct evaporative cooling with condensate into the air before entering the condensing system can enhance the system performance and protect the environment.

\section{Introduction}

Air conditioning systems are the major energy consumers in office building, hotel, central library, hospital, shopping mall, residential and others building. Many literatures reported that in commercial building, air conditioning systems account almost half of the total power consumption, and being the single biggest consumers [1-6]. It is also found that another building consumes more than $50 \%-70 \%$ for HVAC (Heating, Ventilating, and Air Conditioning) of total electrical energy use [7-9]. Therefore, their efficiencies has a significant effect on the overall energy performance of these buildings.

A major concern in vapor compression refrigeration cycle is power consumption, especially for split type air conditioning using air-cooled condensers instead of water-cooled condenser. The surrounding air temperatures is directly use to cooled the condenser, therefore, in the area with hot

\footnotetext{
* Corresponding author.

E-mail address: azridjal.aziz@lecturer.unri.ac.id
}

https://doi.org/10.37934/arfmts.86.1.140153 
temperature, the condenser temperature and pressure are increased considerably which consequently increases the condenser pressure therefore the increase in the power consumption.

The cooling capacity will decrease with increasing condenser temperature which consequently compressor power consumption increase. On the other hands the reducing condenser temperature will reduce condenser pressure which results reduce compressor power consumption [10]. The performance of air conditioning system is enhanced with decreasing inlet air temperature to the condenser. The pressures ratio across the compressor is reduced which results in reduction of power consumption, increasing cooling capacity and enhancing COP. The application of direct evaporative cooling before ambient air entering the condenser is the easiest method for decreasing inlet air temperature to the condenser [11-13]. Evaporative cooling technologies could be classified into direct evaporative cooling (DEC), indirect evaporative cooling (IEC) and combined system evaporative cooling (direct/indirect cooling) [14,15]. Piyanut et al. [16] reported the environmentally-friendly and energy efficient refrigerant for refrigeration systems that new azeotropic refrigerant mixture of hydrofluorocarbons and hydrocarbon that can retrofit in the refrigeration system using R404A. The environmentally-friendly and energy efficient refrigerant have been used in refrigeration system with evaporative cooling application.

Jassim [17] reported the evaluation of thermal performance the water mist assisted for air cooled air conditioning. It has been concluded that due to the combined of water mist with air cooled condenser, the cooling capacity was increased by $17.5 \%$, and the compressor power consumption was reduced by $15.5 \%$. Harby et al., [18] presented an extensive review of the state-of-the-art performance improvement of evaporative condensers used in residential cooling systems: refrigeration, air-conditioning, and heat pump systems. The experimental research on spray evaporative cooling system applied to air-cooled chiller condenser show that the power of the compressor is reduced, while the COP by $4 \%-8 \%$ and contributes to an electricity savings of $2.37 \%$ to $13.53 \%$ [19]. Yang et al., [14] developed the theoretical performance analysis of a new hybrid air conditioning system in hot-dry climate using the fresh air conditioner that can switch its work mode to adapt to different climate conditions.

Many scholars have done experimental research on evaporative cooling system combined with condenser using different type of evaporative pad. Martínez et al., [20] has been modified the chiller unit by placing evaporative cooling pads before the condenser to improve performance and reduce the energy consumption of an $8.6 \mathrm{MW}$ air cooled chiller. Zaidan et al., [21] presented the performance enhancement by adding a wet pad in Vapor Compression Cooling System. This enhancement increases the cooling capacity and COP by nearly $20 \%$ and $15 \%$, respectively with reduce electric consumption up to $15 \%$. The investigation using different commercial cooling pad thicknesses and climatic conditions for energy savings on a split air-conditioning has been developed by Harby and Al-Amri [22]. Jain and Hindoliya [23] studied the Experimental performance of new evaporative cooling pad materials. Barzegar et al., [24] evaluated the performances of cellulosic pads made out of Kraft and NSSC corrugated papers as evaporative media, the results indicated that cooling efficiency increase with decrease of air velocity and water consumption increases with the increase of air velocity. Martínez et al., [25] reported the energy performance of split air-conditioner using variable thickness evaporative cooling pads coupled to the condenser. Ndukwu et al., [26] presented the exegetic performance indicators of a direct evaporative cooling system with different cooling pads.

Evaporative cooling technologies for air-cooled chillers for building energy performance improvement has been presented by Yu et al., [27], the cooling effectiveness can be maximized with lesser water consumption. Kabeel et al., [28] reported the performance evaporative Air-Cooled Chiller using cold mist water that cooled by a small amount of the chiller's chilled water. Rafik et al., 
[29] evaluated the Energy Saving of Package Air Conditioner using Spray Type Evaporative cooling (Case Study: A Villa in Kuwait), it can be concluded that COP increased by $42.2 \%$, and power consumption reduced by $14.55 \%$. Chien et al., [30] evaluated the water spray uniformity in an evaporative condenser of a water chiller. Eidan et al., [31] reported the performance enhancement of conditioning system by using direct evaporative cooling in hot climate, the results showed the cooling capacity is increased around 5\%-7.5\% while compressor power and electric current decrease. Faisal et al., [32] studied the effect of pre-cooling inlet air to the condenser on split type air conditioning, the results showed the condensation and evaporation temperatures reduce in decreasing the inlet air temperature to the condenser and improvement air conditioning performance.

The applications of condensate water for improvement the performance of a split air conditioning have been reported by many researchers. Ardita and Subagia [33] presented the use of condensate water in condenser as an additional cooling media intermittently of a split air conditioning, the experimental results showed that refrigeration effect, cooling capacity and COP system increases by $2 \%, 4 \%$ and $7 \%$, respectively where power consumption of compressor decrease by $3 \%$. Ibrahim et al., [34] studied investigation the use of condensate as condenser air pre-cooling on a vapor compression system for performance improvement. Yang et al., [35] reported the effect of condensate water on the performance of split air conditioning system. The results showed that the condensate water could greatly enhance the air conditioning performance in high ambient temperatures.

Based on the literature study above, it is clear what the authors did focused on direct evaporative cooling using condensate to cool the air entering the condenser [33-35]. The production of condensate water by the evaporator in the indoor unit of the split AC system is usually not utilized and discharged into the environment. This study aims to utilize condensate water as direct evaporative cooling to improve split air conditioning performance. It is expected that the use of condensate water will save compressor power consumption due to the decrease in condenser temperature and pressure ratio, thereby increasing the overall COP.

\section{Methodology}

\subsection{Experimental Method Design}

The experimental method used in this study by adding evaporative cooling module (EC) in side back of condenser where the ambient air will flow into EC module before entering condenser. The schematic diagram of apparatus as shown in Figure 1 was modified from SAC that has compressor power was $0,67 \mathrm{~kW}$ with cooling capacity $0.74 \mathrm{TR}$. HCR-22 refrigerant as hydrocarbon refrigerant was used as working fluid with optimum charge for best performance was $300 \mathrm{~g}$ [36-40].

The detail of data recording in each test was as follows: Evaporator outlet temperature $\left(\mathrm{T}_{\mathrm{e} \text { out }}\right)$, Compressor outlet temperature $\left(\mathrm{T}_{\mathrm{c} \text { out }}\right)$, Evaporator inlet temperature $\left(\mathrm{T}_{\mathrm{e}}\right.$ in $)$, Test room temperature $\left(\mathrm{T}_{\mathrm{r} 1}\right)$, Test room temperature $\left(\mathrm{T}_{\mathrm{r} 2}\right)$, Test room temperature $\left(\mathrm{T}_{\mathrm{r} 3}\right)$, Surrounding temperature $\left(\mathrm{T}_{\text {surr }}\right)$, Dry bulb temperature of condenser air inlet $\left(\mathrm{T}_{\mathrm{db}}\right.$ in $)$, Wet bulb temperature of condenser air inlet $\left(\mathrm{T}_{\mathrm{wb} \text { in }}\right)$, Dry bulb temperature of condenser outlet $\left(\mathrm{T}_{\mathrm{db} \text { out }}\right)$, Wet bulb temperature of condenser outlet, $\left(\mathrm{T}_{\mathrm{wb} \text { out }}\right)$, Evaporator outlet pressure $\left(\mathrm{P}_{\mathrm{e} \text { out }}\right)$, Compressor outlet pressure $\left(\mathrm{P}_{\mathrm{c} \text { out }}\right)$, Evaporator inlet pressure $\left(\mathrm{P}_{\mathrm{e}}\right.$ in $)$, Electric current of compressor $\left(\mathrm{I}_{\mathrm{c}}\right)$ and Electric voltage of compressor $\left(\mathrm{V}_{\mathrm{c}}\right)$. 


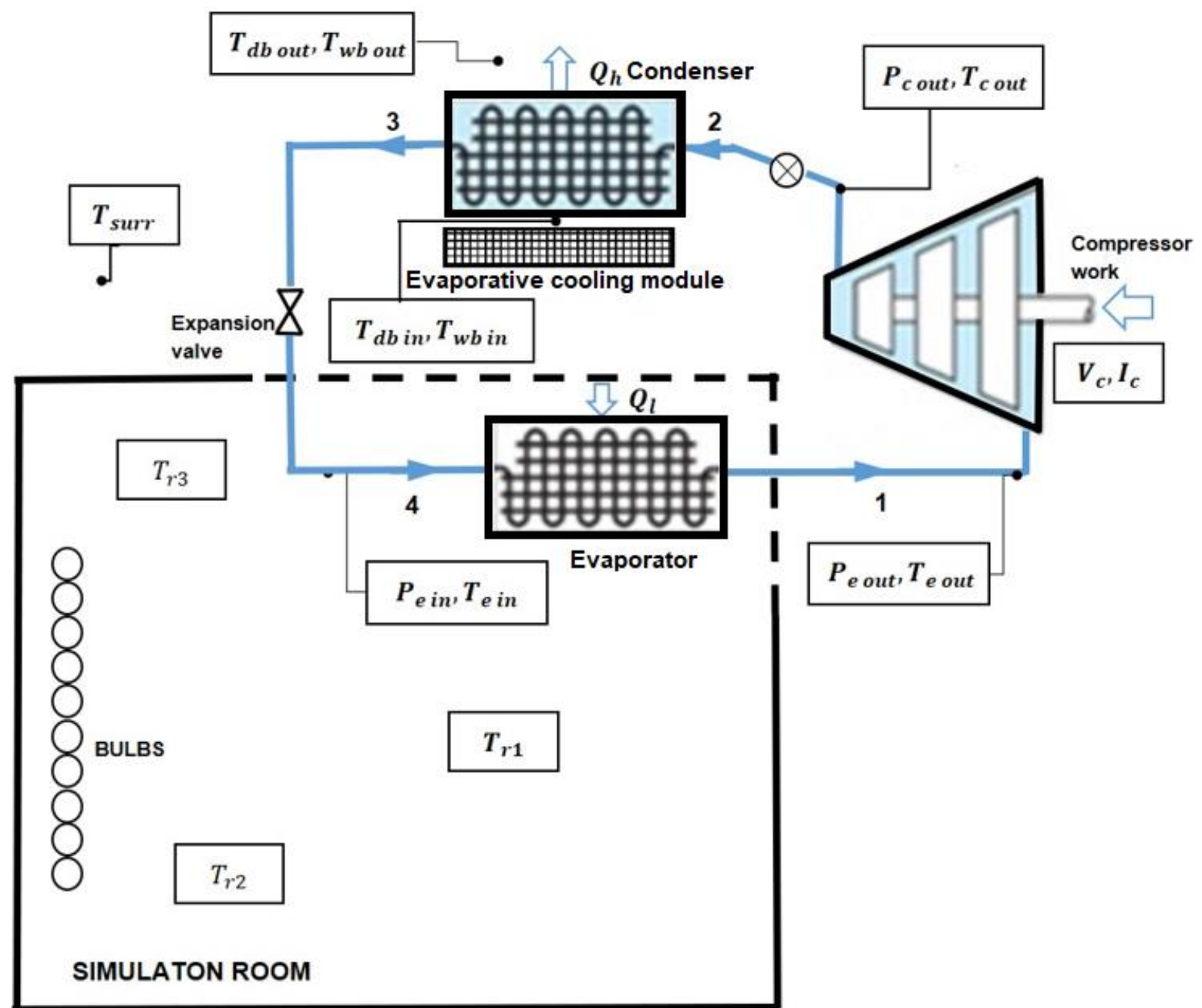

Fig. 1. Schematic diagram of Split Air Conditioning (SAC) apparatus with evaporative cooling module [36-39]

The measurement devices used in this study were analogue refrigerant pressure gauge (accuracy \pm 5 psi for high pressure and \pm 1 psi for low pressure), digital thermometer (accuracy $\pm 0,1^{\circ} \mathrm{C}$ ), $\mathrm{K}$ type thermocouple with omega TC-08 data acquisition module (accuracy $0.2 \% \pm 0.5$ Temperature ${ }^{\circ} \mathrm{C}$ and has a resolution of better than $0.1^{\circ} \mathrm{C}$ ), ampere-meter (accuracy $\pm 2.0 \%$ and 3 digits), voltmeter (accuracy $\pm 1.0 \%$ and 3 digits), refrigerant digital weight scale for mass charge (accuracy \pm 10 gram) [36-39]. The experimental data were captured continuously for 2 hours every 5 minutes. The dynamic operation characteristics were tested under condition of the room temperature around $20^{\circ} \mathrm{C}, 23^{\circ} \mathrm{C}$ and $27^{\circ} \mathrm{C}$ for cooling load $1000 \mathrm{~W}, 2000 \mathrm{~W}$ and $3000 \mathrm{~W}$, respectively. Figure 2 shows photograph of outdoor unit (condenser) with evaporative cooling module using condensate drain water hose. Figure 3 shows schematic detail of picture of outdoor unit (condenser) and evaporative cooling module using condensate drain water to reduce entering temperature of air to inlet of condenser. Figure 3 shows schematic detail of outdoor unit (condenser) with evaporative cooling module using condensate drain water, this detail picture was modified from Chaktranond and Doungsong [41]. The uncertainty of experimental results may be originated from measuring errors of variables such as temperature, and pressure. Using a method suggested by Moffat [42], International Atomic Energy Agency (IAEA) [43] and Ibrahim et al., [34], the uncertainties of temperature and pressure were estimated to be $\pm 1.07 \%$ and $\pm 2.2 \%$, respectively. 


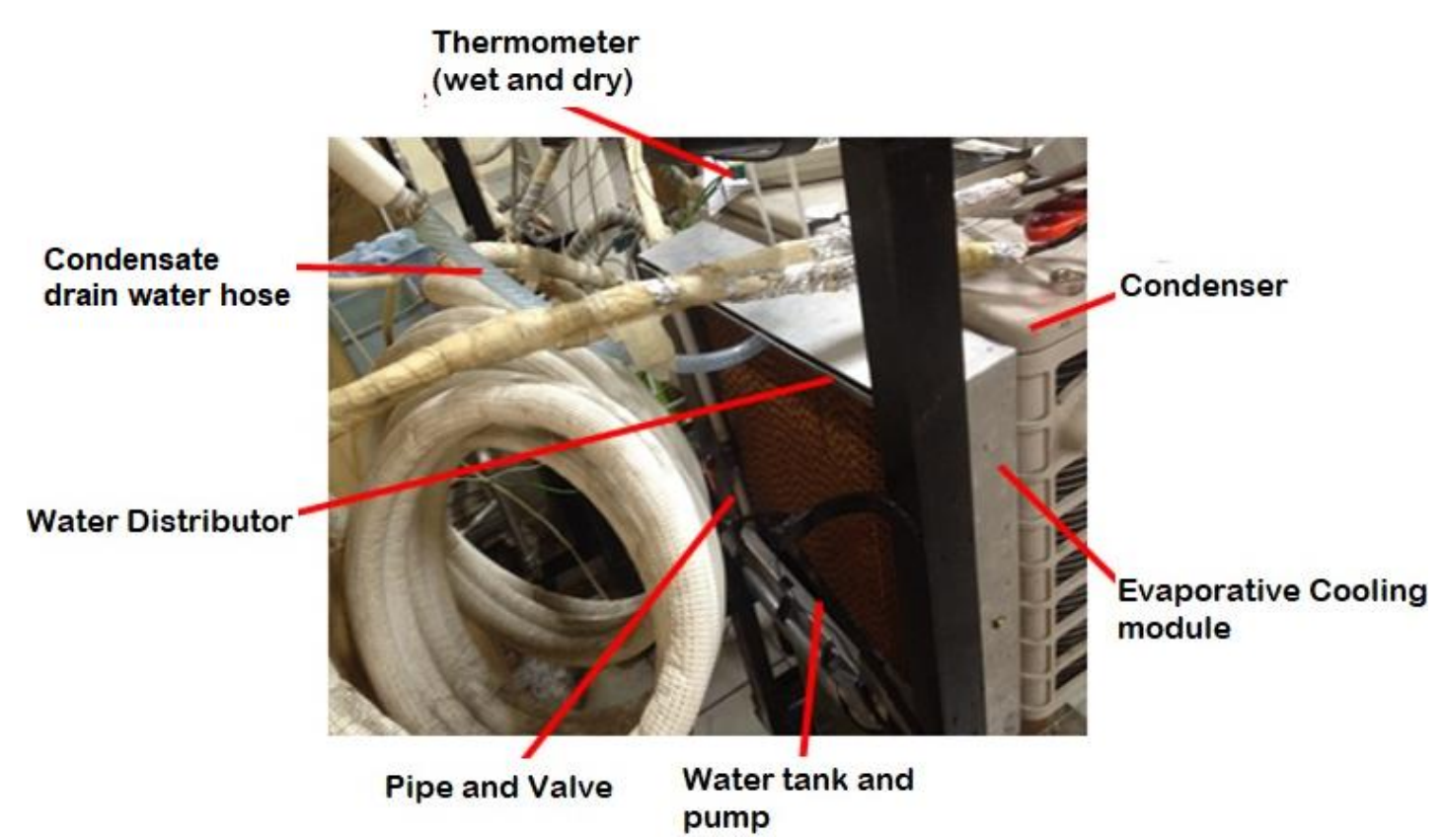

Fig. 2. Photograph of outdoor unit (condenser) with evaporative cooling module using condensate drain water hose

The evaporative cooling module has dimension with size $513 \mathrm{~mm} \times 108 \mathrm{~mm} \times 608 \mathrm{~mm}$ (length $\mathrm{x}$ width $x$ height) and evaporative cooling pad has dimension size $435 \mathrm{~mm} \times 80 \mathrm{~mm} \times 458 \mathrm{~mm}$ (length $x$ width $x$ height). Evaporative cooling module consist of framework, one solenoid valve, two water level switch, one mini submersible pump, one evaporative cooling pad and one water distributor. The evaporative cooling pad, made of cellulose paper with cross-sectional specially treated fluted media, it can absorb and retain water for providing the maximum cooling efficiencies.

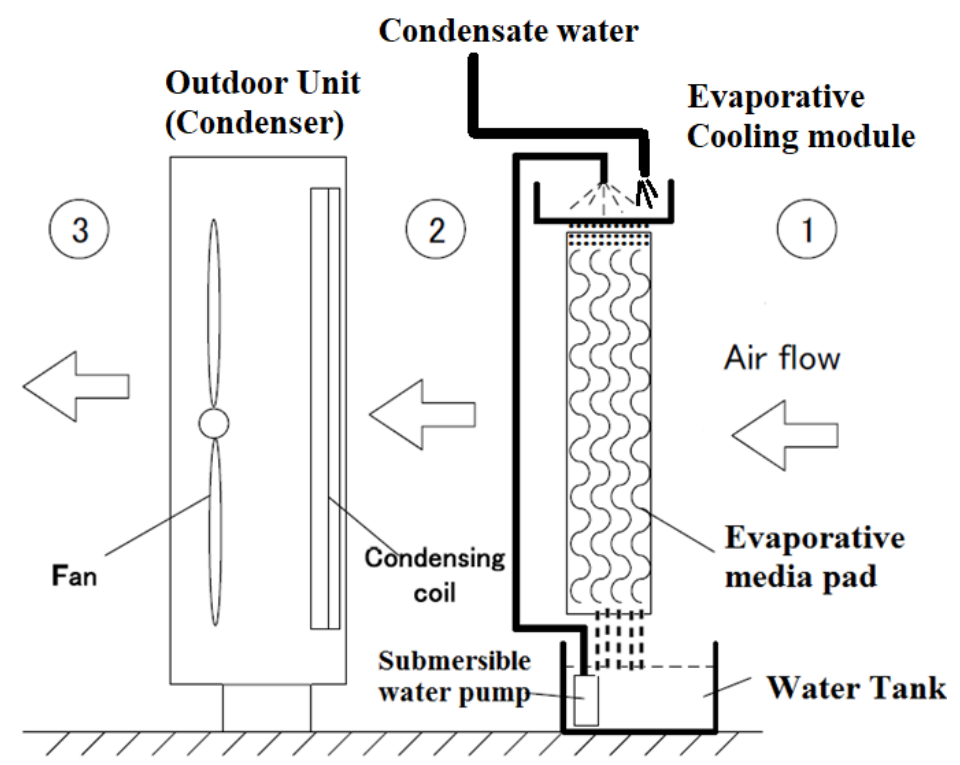

Fig. 3. Schematic detail of outdoor unit (condenser) with evaporative cooling module using condensate drain water modified from Chaktranond and Doungsong [41] 


\subsection{Data Reduction}

The performance of refrigeration cycle is calculated as ideal vapor compression refrigeration cycle. The Coefficient of Performance (COP) is defined as ratio of cooling effect $\left(Q_{L}\right)$ per compressor work input $\left(W_{C}\right)$ and can be expressed as Eq. (1).

COP $=\frac{\text { Cooling Effect }}{\text { Work Input }}=\frac{Q_{L}}{W_{C}}$

The cooling effect of a refrigeration system $\left(Q_{L}\right)$ is the rate of heat removal from the refrigerated space is defined as Eq. (2).

$Q_{L}=\dot{m}\left(h_{1}-h_{4}\right)$

Where $\dot{m}$ is the refrigerant mass flowrate, $h_{1}$ and $h_{4}$ are enthalpy at the outlet and inlet line of evaporator, respectively. Cooling effect is often expressed in terms of tons of refrigeration. The cooling effect can be expressed as capacity of a refrigeration system that can freeze 1 ton ( $2000 \mathrm{lbm})$ of liquid water at $0^{\circ} \mathrm{C}\left(32^{\circ} \mathrm{F}\right)$ into ice at $0^{\circ} \mathrm{C}$ in $24 \mathrm{~h}$ is said to. One ton of refrigeration (TR)is equivalent to $211 \mathrm{~kJ} / \mathrm{min}$ or $200 \mathrm{Btu} / \mathrm{min}$.

The heat rejected from the condenser $\left(Q_{h}\right)$ can be calculated as Eq. (3).

$Q_{h}=\dot{m}\left(h_{2}-h_{3}\right)$

Where $h_{2}$ is enthalpy at compressor outlet, and $h_{3}$ is enthalpy at condenser exit. The compressor power work input $\left(W_{C}\right)$ can be calculated from the following Eq. (4).

$W_{C}=V \times I \times \cos \emptyset$

Where $W_{C}$ is work input of compressor power consumption and $V, I$, and $\cos \emptyset$ are electric voltage, electric current, and the electric power factor, respectively. The refrigerant mass flow rate of HCR-22 is calculated by Eq. (5).

$\dot{m}=\frac{W_{C}}{h_{2}-h_{1}}$

The experimental data analysis in this study are made with the following assumptions: negleted the pressure drop across the condenser and evaporator (usually about $7 \%$ and $5 \%$ ), the evaporator and condenser outlets assumed in saturated states, negleted heat gains and heat losses on the refrigerant lines [10,34].

\section{Results}

\subsection{Inlet and Outlet Temperature in Condenser with and without Evaporative Cooling}

Figure 4 shows the time variation of condenser inlet and outlet temperature in condition with and without evaporative cooling (EC) as effect of cooling load (OW and 2000W). Figure 4(a) and Figure 4(b) shows the inlet temperature and outlet temperature in condenser with and without EC using zero load (OW) and 2000W cooling load, respectively. As seen in Figure 4(a), there is a change in air temperature inlet entering the condenser after flowing out from evaporative cooling. It can be seen 
that the ambient temperature during $\mathrm{OW}$ cooling load is $30.95^{\circ} \mathrm{C}$ in average, where the temperature of the air entering the condenser with EC is $29.14^{\circ} \mathrm{C}$ in average. Figure $4(\mathrm{~b})$ shows the ambient temperature in the test with $2000 \mathrm{~W}$ cooling load is $31.51^{\circ} \mathrm{C}$ in average and the temperature of the air entering the condenser with $\mathrm{EC}$ is $30.96^{\circ} \mathrm{C}$ in average. The air temperature entering the condenser is lower than ambient temperature due to application of the direct evaporative cooling, while outlet temperature also lowers as effect of EC. The temperature difference at inlet and outlet condenser with $2000 \mathrm{~W}$ cooling load lower than $\mathrm{OW}$ as effect of cooling load. When water evaporates, it turns from liquid to vapor. As it does so, the highest-energy particles leave the water first, and this leads to a drop in temperature. This is causing air temperature entering the condenser lower than the ambient air temperature. The temperature of the air passing through EC can be lowered by up to $1^{\circ} \mathrm{C}$ $-3^{\circ} \mathrm{C}$ in this study.

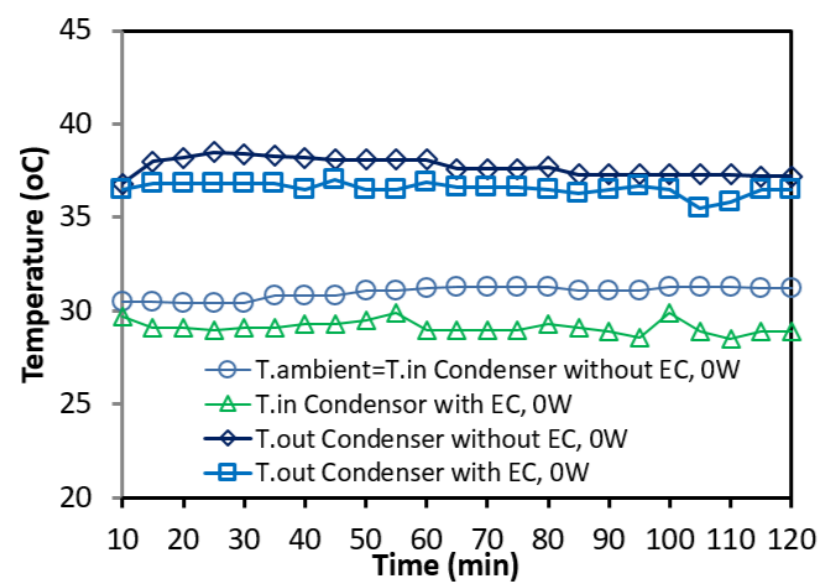

(a)

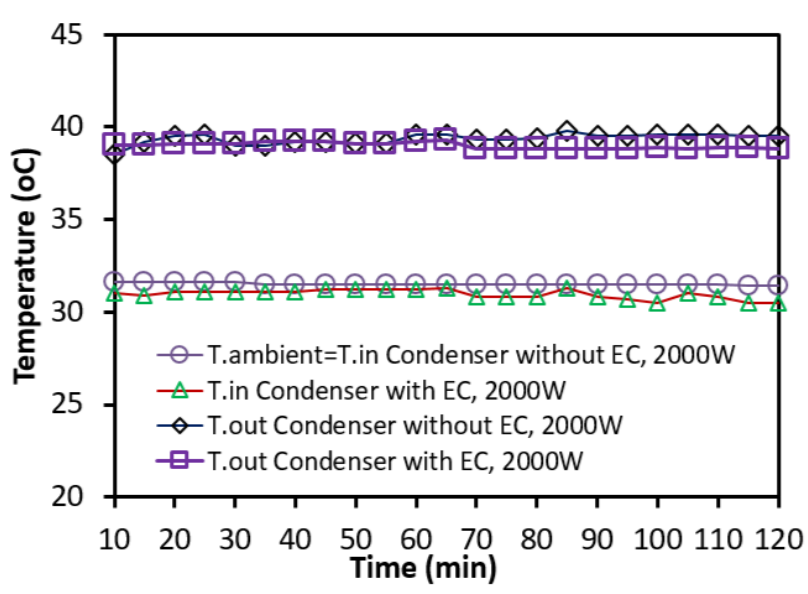

(b)

Fig. 4. Time variation and temperature of ambient, inlet and outlet condenser with and without Evaporative Cooling; (a) cooling load OW, (b) cooling load 2000W

\subsection{Outlet Temperature in Condenser and Test Room Temperature with and without Evaporative Cooling}

Figure 5 shows the time variation of condenser outlet temperature and test room temperature in condition with and without evaporative cooling (EC) as effect of cooling load (OW and 2000W) where Figure 5(a) and Figure 5(b) show the time variation in of cooling load OW and 2000W, respectively. As shown in Figure 5(a), the graph of condenser temperature and room temperature, it shows that the outlet temperature of condenser without EC and without cooling load (OW) reaches an average temperature of $37.3^{\circ} \mathrm{C}$ and the room temperature reaches an average of $19.6^{\circ} \mathrm{C}$. Meanwhile, the outlet temperature of the condenser with EC and without cooling load reaches an average temperature of $36.3^{\circ} \mathrm{C}$ and the room temperature reaches an average of $19.04^{\circ} \mathrm{C}$. Figure 5 (b) show the outlet temperature of the condenser without applied EC with $2000 \mathrm{~W}$ cooling load reaches an average temperature of $38.9^{\circ} \mathrm{C}$ and room temperature reaches an average of $26.8^{\circ} \mathrm{C}$. Then, the outlet temperature of the condenser with EC and cooling load of $2000 \mathrm{~W}$ reached an average temperature of $38.7^{\circ} \mathrm{C}$ and the room temperature reached an average of $24.1^{\circ} \mathrm{C}$. It can be concluded that the outlet temperature of the condenser using EC is lower than the outlet temperature of the condenser without EC. This means that it is the same as the temperature entering the condenser, using EC, the outlet temperature from the condenser is lower than the standard SAC conditions or without EC, because the input temperature to the condenser is lower than the ambient temperature as effect of applied EC. 


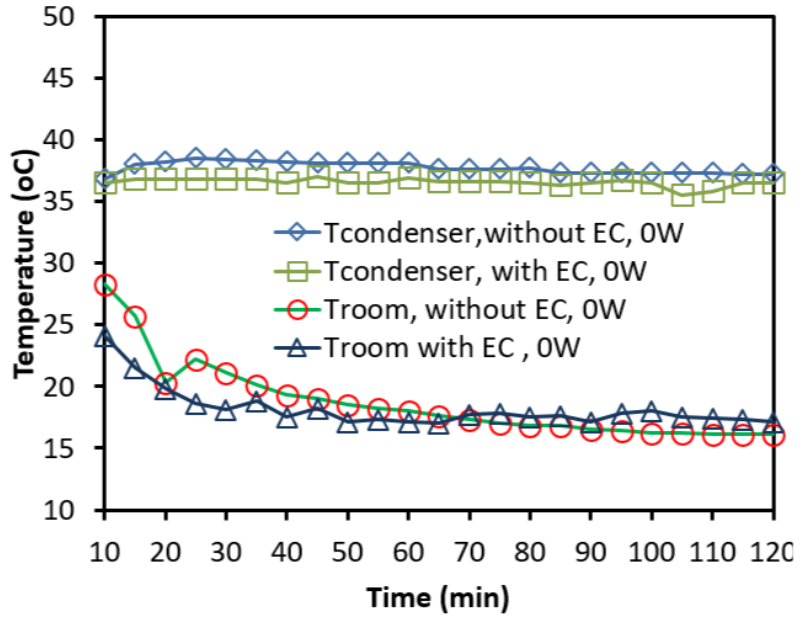

(a)

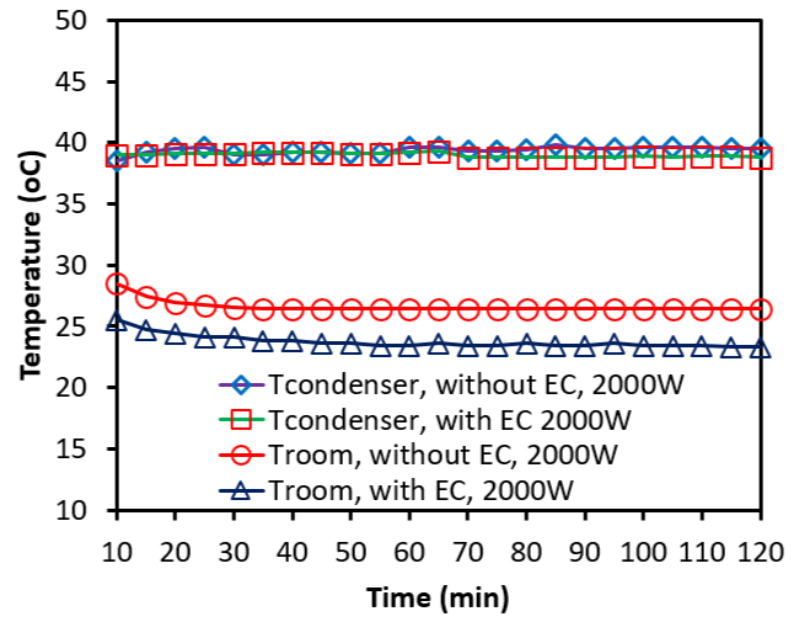

(b)

Fig. 5. Time variation of condenser outlet temperature and room temperature with and without Evaporative Cooling; (a) cooling load OW, (b) cooling load 2000W

\subsection{Condenser Pressure and Evaporator Pressure with and without Evaporative Cooling}

Time variation of condenser pressure as affected of evaporative cooling application in condition cooling load OW (Figure 6(a)) and 2000w (Figure 6(b)) is shown in Figure 6. As seen in Figure 6, the condenser pressure without EC with cooling load of $\mathrm{OW}$ has an average pressure of 201.4 psi, whereas in test result with EC with cooling load of OW has an average condenser pressure of $200 \mathrm{psi}$. Then the condenser pressure without EC with cooling load of $2000 \mathrm{~W}$ has an average pressure of 219.2 psi and the condenser pressure with EC with cooling load of $2000 \mathrm{~W}$ has an average condenser pressure of 209.4 psi. It can be concluded that the condenser pressure when EC applied is lower than the condenser pressure without EC, decrease about $4.7 \%$. The same results were obtained for the evaporator pressure, where the evaporator pressure with EC was lower than the evaporator pressure without EC.

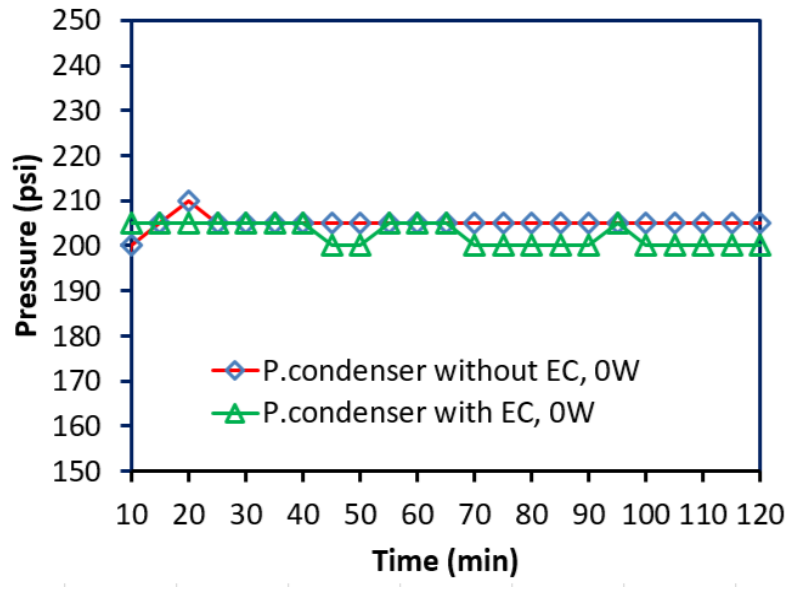

(a)

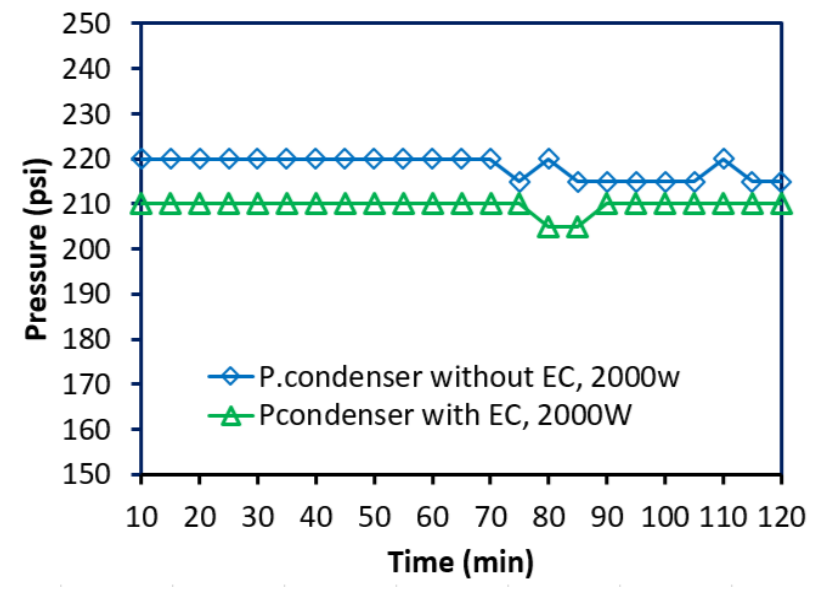

(b)

Fig. 6. Time variation of condenser pressure with and without Evaporative Cooling; (a) cooling load OW, (b) cooling load $2000 \mathrm{~W}$ 
Figure 7 shows time variation of evaporator pressure as affected of evaporative cooling application in condition cooling load OW (Figure 7(a)) and 2000w (Figure 7(b)). The test results show that (Figure 6) when the condenser pressure decrease, the evaporator pressure also decreases (Figure 7). Where the condenser pressure is related to the electricity consumption of the compressor work, the lower the condenser pressure, the lower the electricity consumption and vice versa. So, it can be stated that the application of EC using condensate water as cooling media reduce the condenser pressure and evaporator pressure which reduces the electrical energy consumption of the compressor.

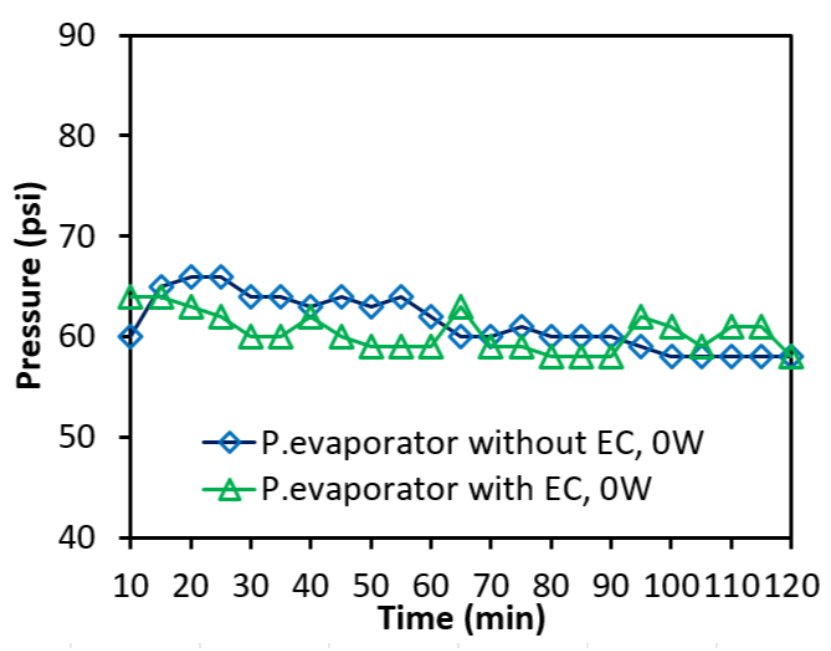

(a)

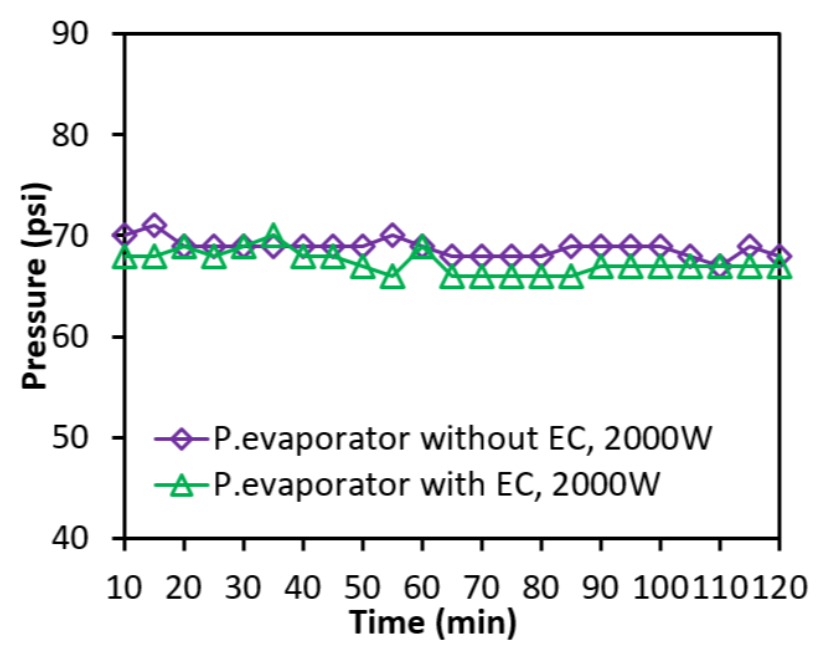

(b)

Fig. 7. Time variation of evaporator pressure with and without Evaporative Cooling; (a) cooling load OW, (b) cooling load $2000 \mathrm{~W}$

\subsection{Compressor Work and Heat Capacity with and without Evaporative Cooling}

Figure 8 shows the comparison of compressor work in average with and without Evaporative Cooling (Figure 8(a)) and heat capacity in condenser and evaporator in average (Figure 8(b)) in operating condition with cooling load OW and 2000W. As shown in Figure 8(a), the compressor work in test condition with cooling load OW without EC applied has an average of $0.60 \mathrm{~kW}$ and after application of EC the average decreases to $0.56 \mathrm{~kW}$. While the compressor work on the test with a cooling load of $2000 \mathrm{~W}$ before application of EC has an average of $0.64 \mathrm{~kW}$ and after application of $\mathrm{EC}$, compressor work decreases in the average to $0.59 \mathrm{kw}$. It means that the application of EC by utilizing condensate water reduce compressor work of energy consumption. The same result also occurs in the condenser side, where in the application of EC, the heat rejected in the condenser is lower in both cooling load condition $\mathrm{OW}$ and 2000W. Meanwhile, the cooling effect in the evaporator tends to be similar as an insignificant decrease as shown in Figure 8(b).

Figure 9 shows time variation of compressor work as affected of evaporative cooling application in condition cooling load OW (Figure 9(a)) and 2000w (Figure 9(b)). The test results show that when evaporative cooling is applied, the compressor work decreases for both 0w cooling load and 2000W cooling load. it can be stated that the application of evaporative cooling using condensate water as cooling media reduce the compressor work of electrical energy consumption. 


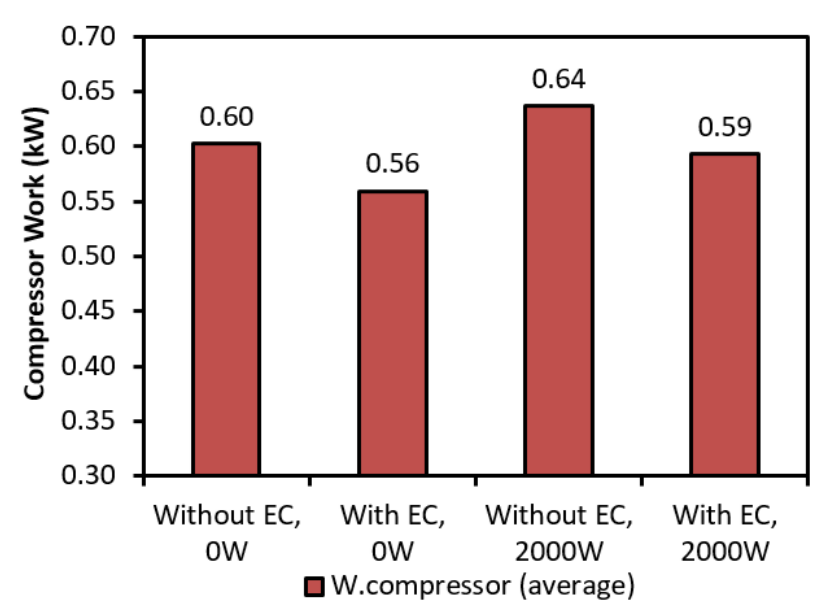

(a)

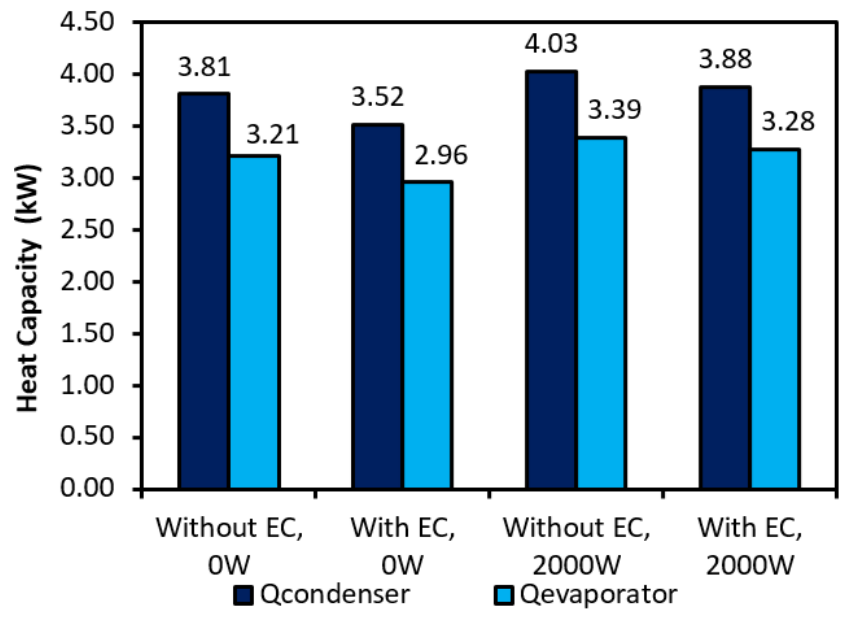

(b)

Fig. 8. Comparison of compressor work in average with and without Evaporative Cooling (a) and heat capacity in condenser/evaporator in average (b) in condition cooling load $0 \mathrm{~W}$ and 2000W.

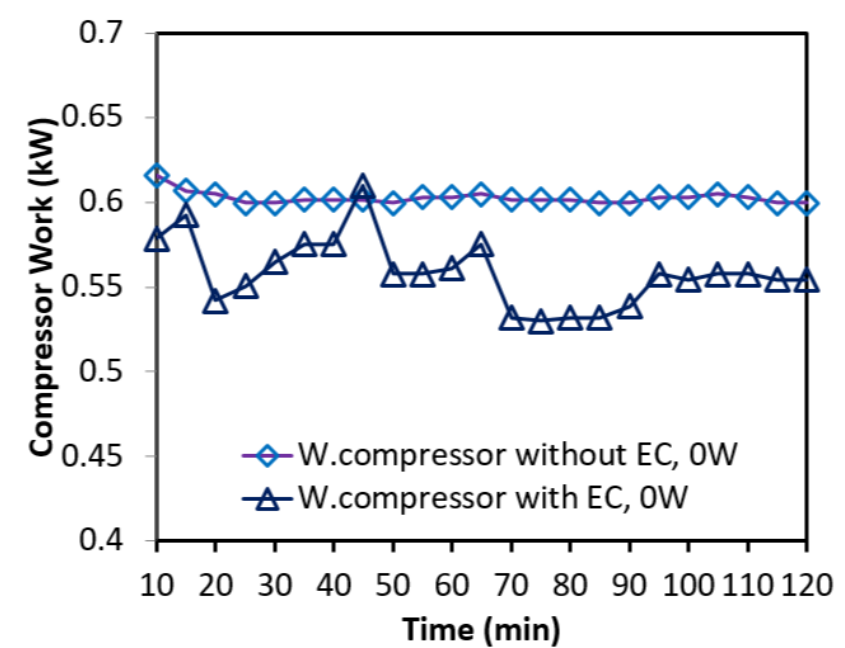

(a)

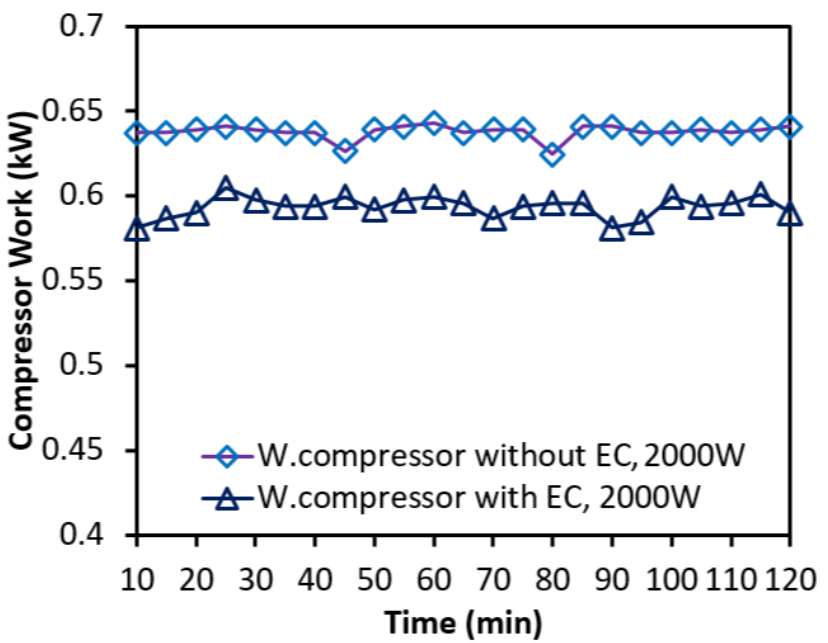

(b)

Fig. 9. Comparison of compressor work with and without Evaporative Cooling; (a) cooling load OW, (b) cooling load $2000 \mathrm{~W}$

Figure 10 shows the compressor work energy saving percentage in average with and without Evaporative Cooling in operating condition with cooling load OW and 2000W. As shown in Figure 10, the test results show that when evaporative cooling is applied, the compressor work energy saving percentage are $7.79 \%$ and $7.32 \%$ for $0 \mathrm{w}$ cooling load and $2000 \mathrm{~W}$ cooling load, respectively. It can be concluded that the application of evaporative cooling using condensate water as a cooling media, provides compressor electrical energy consumption saving about $7 \%$ in average. The experimental results from other researchers also concluded that there were 7.3\% energy saving in compressor work, an electricity savings of $2.37 \%-13.53 \%$ and reducing electricity comsumption up to $15 \%$ $[19,21,35]$. 


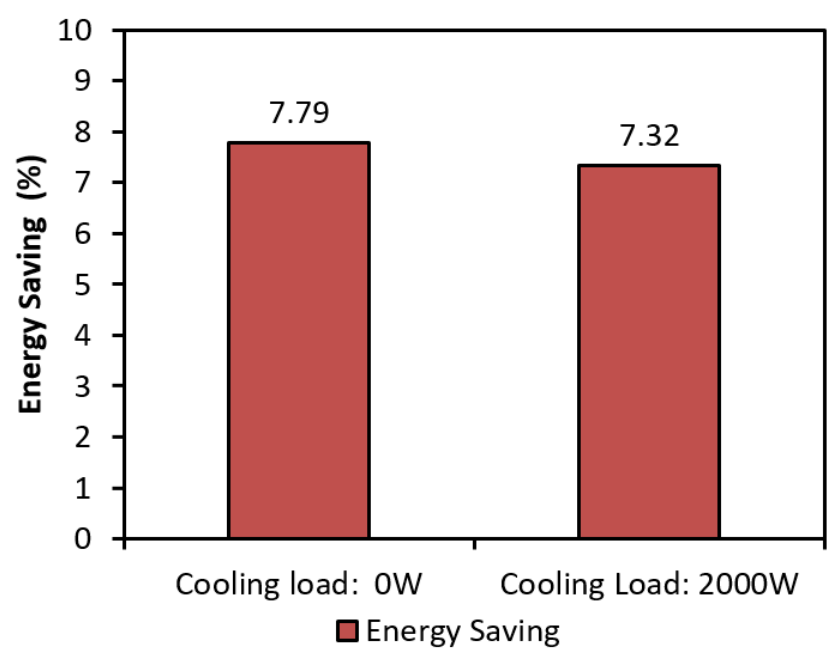

Fig. 10. Compressor work energy saving percentage with and without Evaporative Cooling in condition cooling load OW and 2000W

\subsection{Coefficient of Performance (COP) with and without Evaporative Cooling}

Figure 11 shows the comparison of Coefficient of Performance (COP) (Figure 11(a)) and COP enhancement (Figure 11(b)) with and without evaporative cooling in operating condition with cooling load OW and 2000W. As shown in Figure 11, the test results show that COP increase when evaporative cooling is applied (Figure 11(a)). The COP enhancement percentage are $1.05 \%$ and $4.17 \%$ for $0 \mathrm{w}$ cooling load and 2000W cooling load, respectively on application of evaporative cooling (Figure 11(b)).

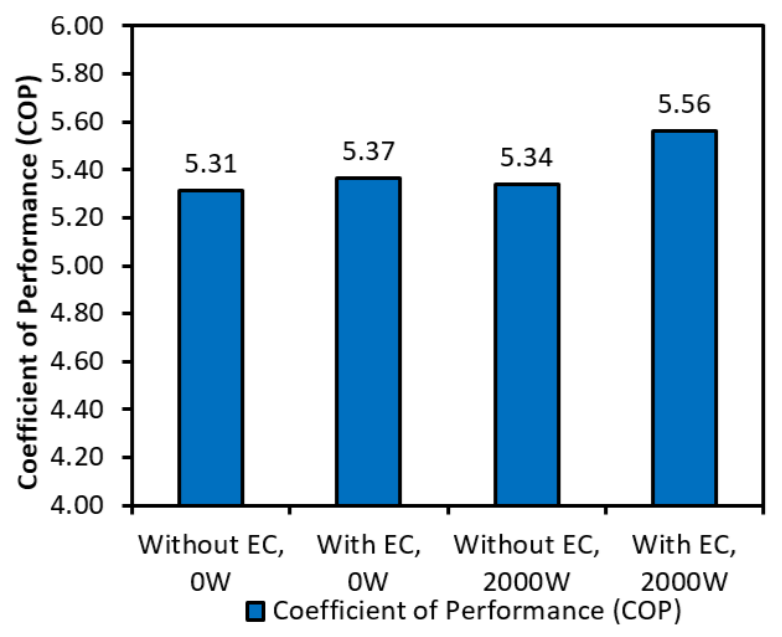

(a)

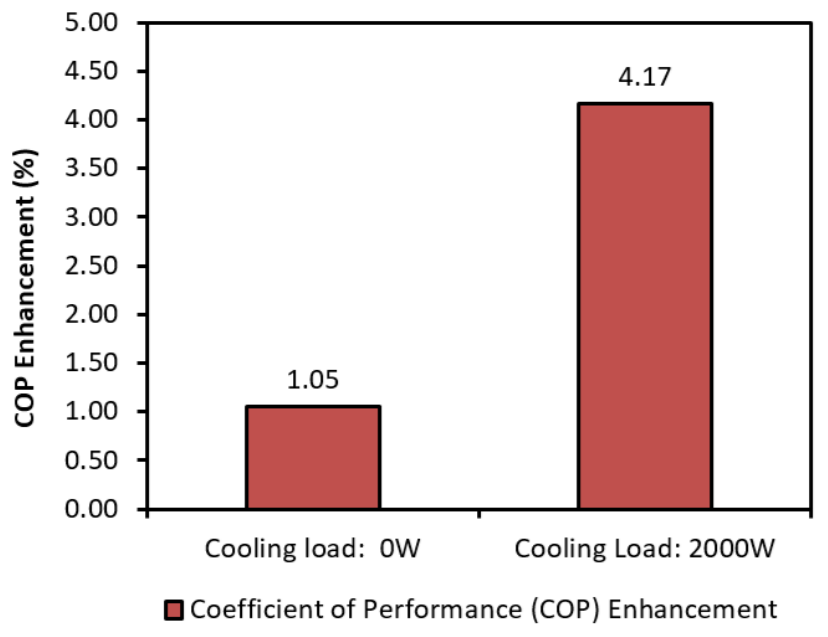

(b)

Fig. 11. Comparison of Coefficient of Performance (COP) with and without Evaporative Cooling in condition cooling load OW and 2000W; (a) average COP, (b) average percentage of COP enhancement

It can be concluded that the application of evaporative cooling using condensate water as a cooling media, Coefficient of Performance increase with decreasing inlet condenser temperature. These results confirm with some other studies were Yang et al., [19] reported the COP (Coefficient of Performance) of the air-cooled chiller increases by $4 \%-8 \%$ after the application of the evaporative cooling system and Zaidan et al., [21] reported the COP with wet pad application increases by $15 \%$. 


\section{Conclusions}

The performance evaluation of a split air conditioning utilizing condensate water with and without direct evaporative cooling to pre-cool the air entering the condenser is presented here. The result show that the compressor work consumption is decreased by $7 \%$ in average as a result of the decrease in condenser pressure by $4.7 \%$ when the air temperature entering the condenser is lowered by application of evaporative cooling by utilizing condensate water. The coefficient of performance (COP) is enhanced by $4.17 \%$ in average. This is a clear indication that application of evaporative cooling can be used to improve the split air conditioning performance, especially for split air conditioning with large cooling capacity which produces reasonable amount of condensate drain water. There is the technical advantage with decreasing of condenser pressure in addition to lower compressor power consumption is the compressor lifetime tend to have better life expectancy due to decreased thermal stresses on the parts of compressor.

\section{Acknowledgement}

This research was funded by a grant from Ministry of Research, Technology and Higher Education of Indonesia (Grant number: 095/SP2H/LT/DRPM/IV/2017).

\section{References}

[1] Allouhi, Amine, Youness El Fouih, Tarik Kousksou, Abdelmajid Jamil, Youssef Zeraouli, and Youssef Mourad. "Energy consumption and efficiency in buildings: current status and future trends." Journal of Cleaner Production 109 (2015): 118-130. https://doi.org/10.1016/j.jclepro.2015.05.139

[2] Roslizar, Aiman, M. A. Alghoul, B. Bakhtyar, Nilofar Asim, and K. Sopian. "Annual energy usage reduction and cost savings of a school: End-use energy analysis." The Scientific World Journal 2014 (2014). https://doi.org/10.1155/2014/310539

[3] Inayati, I., F. X. N. Soelami, and R. Triyogo. "Identification of existing office buildings potential to become green buildings in energy efficiency aspect." Procedia Engineering $170 \quad$ (2017): $320-324$. https://doi.org/10.1016/j.proeng.2017.03.040

[4] Sol, Daniel Coll, Aryadevi Remanidevi Devidas, M. S. Anjana, and Maneesha Vinodini Ramesh. "Design and implementation of context aware cyber physical system for sustainable smart building." In 2018 International Conference on Smart Grid and Clean Energy Technologies (ICSGCE), pp. 162-167. IEEE, 2018. https://doi.org/10.1109/ICSGCE.2018.8556726

[5] Imran, Amer Matrood, Khalid Almusawi, and Jaafar Ali Mahdi. "Experimental and Theoretical Investigation of Reducing Energy Consumption for a Building using Geothermal Water through the Glass." In IOP Conference Series: Materials Science and Engineering, vol. 671, no. 1, p. 012020. IOP Publishing, 2020. https://doi.org/10.1088/1757899X/671/1/012020

[6] Saidur, Rahman, M. Hasanuzzaman, T. M. I. Mahlia, N. A. Rahim, and H. A. Mohammed. "Chillers energy consumption, energy savings and emission analysis in an institutional buildings." Energy 36, no. 8 (2011): 5233 5238. https://doi.org/10.1016/i.energy.2011.06.027

[7] Alajmi, Turki, and Patrick Phelan. "Modeling and forecasting end-use energy consumption for residential buildings in Kuwait using a bottom-up approach." Energies 13, no. 8 (2020): 1981. https://doi.org/10.3390/en13081981

[8] Akata, Aloys Martial Ekoe A., Donatien Njomo, and Basant Agrawal. "Assessment of Building Integrated Photovoltaic (BIPV) for sustainable energy performance in tropical regions of Cameroon." Renewable and Sustainable Energy Reviews 80 (2017): 1138-1152. https://doi.org/10.1016/i.rser.2017.05.155

[9] Ayoub, Nasser, Farayi Musharavati, Shaligram Pokharel, and Hossam A. Gabbar. "Energy consumption and conservation practices in Qatar-A case study of a hotel building." Energy and Buildings 84 (2014): 55-69. https://doi.org/10.1016/i.enbuild.2014.07.050

[10] Hajidavalloo, E., and H. Eghtedari. "Performance improvement of air-cooled refrigeration system by using evaporatively cooled air condenser." International Journal of Refrigeration 33, no. 5 (2010): 982-988. https://doi.org/10.1016/i.ijrefrig.2010.02.001

[11] Dwivedi, S., and B. A. Shah. "Review and experimental study on performance improvement of split air conditioner by reducing inlet air temperature to the ODU." In Journal of Physics: Conference Series, vol. 1706, no. 1, p. 012211. IOP Publishing, 2020. https://doi.org/10.1088/1742-6596/1706/1/012211 
[12] Shah, Balkrushna, Shivam Dwivedi, Ath Singhal. "Energy Saving in Split Air Conditioner using Evaporative Cooling Pad at the ODU." International Journal of Innovative Technology and Exploring Engineering (IJITEE) 9, no. 1 (2019): 1858-1862. https://doi.org/10.35940/ijitee.A4765.119119

[13] Aziz, Azridjal, Rahmat Iman Mainil, Afdhal Kurniawan Mainil, and Hendra Listiono. "Effect of water temperature and air stream velocity on performance of direct evaporative air cooler for thermal comfort." In AIP Conference Proceedings, vol. 1788, no. 1, p. 030024. AIP Publishing LLC, 2017. https://doi.org/10.1063/1.4968277

[14] Yang, Yang, Chengqin Ren, Zhao Wang, and Baojun Luo. "Theoretical performance analysis of a new hybrid air conditioning system in hot-dry climate." International Journal of Refrigeration 116 (2020): 96-107. https://doi.org/10.1016/i.ijrefrig.2020.03.015

[15] Amer, O., R. Boukhanouf, and H. G. Ibrahim. "A review of evaporative cooling technologies." International Journal of Environmental Science and Development 6, no. 2 (2015): 111-117. https://doi.org/10.7763/IJESD.2015.V6.571

[16] Saengsikhiao, Piyanut, Juntakan Taweekun, Kittinan Maliwan, Somchai Sae-ung, and Thanansak Theppaya. "Development of Environmentally-Friendly and Energy Efficient Refrigerant for Medium Temperature Refrigeration Systems." Journal of Advanced Research in Materials Science 71, no. 1 (2020): 12-31. https://doi.org/10.37934/arms.71.1.1231

[17] Jassim, Najim Abid. "Thermal performance evaluation of water mist assisted air conditioner." International Journal of Computer Applications 105, no. 16 (2014): 5-10.

[18] Harby, K., Doaa R. Gebaly, Nader S. Koura, and Mohamed S. Hassan. "Performance improvement of vapor compression cooling systems using evaporative condenser: An overview." Renewable and Sustainable Energy Reviews 58 (2016): 347-360. https://doi.org/10.1016/j.rser.2015.12.313

[19] Yang, Hua, Lan Rong, Xuanchen Liu, Liansheng Liu, Man Fan, and Na Pei. "Experimental research on spray evaporative cooling system applied to air-cooled chiller condenser." Energy Reports 6 (2020): 906-913. https://doi.org/10.1016/i.egyr.2020.04.001

[20] Martínez, Francisco J. Rey, Julio F. San José Alonso, Eloy Velasco Gómez, Ana Tejero González, Paula M. Esquivias, and Javier M. Rey Hernández. "Energy consumption reduction of a chiller plant by adding evaporative pads to decrease condensation temperature." Energies 13, no. 9 (2020): 2218. https://doi.org/10.3390/en13092218

[21] Zaidan, Maki H., Thamir K. Ibrahim, and Aadel A. R. Alkumait. "Performance enhancement by using wet pad in vapor compression cooling system." Journal of Engineering and Technological Sciences 51, no. 1 (2019): 48-63. https://doi.org/10.5614/i.eng.technol.sci.2019.51.1.4

[22] Harby, Khaled, and Fahad Al-Amri. "An investigation on energy savings of a split air-conditioning using different commercial cooling pad thicknesses and climatic conditions." Energy 182 (2019): 321-336. https://doi.org/10.1016/i.energy.2019.06.031

[23] Jain, J. K., and D. A. Hindoliya. "Experimental performance of new evaporative cooling pad materials." Sustainable Cities and Society 1, no. 4 (2011): 252-256. https://doi.org/10.1016/i.scs.2011.07.005

[24] Barzegar, Mahsa, Mohammad Layeghi, Ghanbar Ebrahimi, Yahya Hamzeh, and Manouchehr Khorasani. "Experimental evaluation of the performances of cellulosic pads made out of Kraft and NSSC corrugated papers as evaporative media." Energy Conversion and Management 54, no. 1 (2012): 24-29. https://doi.org/10.1016/j.enconman.2011.09.016

[25] Martínez, Pedro, J. Ruiz, C. G. Cutillas, P. J. Martínez, A. S. Kaiser, and M. Lucas. "Experimental study on energy performance of a split air-conditioner by using variable thickness evaporative cooling pads coupled to the condenser." $\quad$ Applied $\quad$ Thermal $\quad$ Engineering $105 \quad$ (2016): $1041-1050$. https://doi.org/10.1016/i.applthermaleng.2016.01.067

[26] Ndukwu, M. C., F. I. Abam, S. I. Manuwa, and T. A. Briggs. "Exergetic performance indicators of a direct evaporative cooling system with different evaporative cooling pads." International Journal of Ambient Energy 38, no. 7 (2017): 701-709. https://doi.org/10.1080/01430750.2016.1195774

[27] Yu, F. W., K. T. Chan, J. Yang, and R. K. Y. Sit. "Evaporative cooling technologies for air-cooled chillers for building energy performance improvement." Advances in Building Energy Research 10, no. 1 (2016): 10-19. https://doi.org/10.1080/17512549.2015.1040070

[28] Kabeel, A. E., Y. A. F. El-Samadony, and M. H. Khiera. "Performance evaluation of energy efficient evaporatively aircooled chiller." Applied Thermal Engineering $122 \quad$ (2017): $204-213$. https://doi.org/10.1016/j.applthermaleng.2017.04.103

[29] Shiaty, Rafik El, Swilem A. M. S., HilalAbdelwali, and Yousuf Alhendal. "Evaluation of Energy Saving in a Package Air Conditioner with Optimum Atomized Water Spray Type Evaporative System. (Case Study: A Villa in Kuwait)." American Journal of Engineering Research (AJER) 7, no. 12 (2018): 277-285.

[30] Chien, Liang-Han, Jin-Jia Xu, Tien-Fu Yang, and Wei-Mon Yan. "Experimental study on water spray uniformity in an evaporative condenser of a water chiller." Case Studies in Thermal Engineering 15 (2019): 100512. https://doi.org/10.1016/i.csite.2019.100512 
[31] Eidan, Adel A., Kareem J. Alwan, Assaad AlSahlani, and Mohamed Alfahham. "Enhancement of the performance characteristics for air-conditioning system by using direct evaporative cooling in hot climates." Energy Procedia 142 (2017): 3998-4003. https://doi.org/10.1016/j.egypro.2017.12.311

[32] Faisal, Safaa Hameed, Salman Hashim Hammadi, and Saif Saiwam Mutlak. "Experimental Study for the Effect of Pre-Cooling the Condenser Inlet Air of Split Type Air Conditioning Unit." Engineering Journal 22, no. 5 (2018): $67-$ 85. https://doi.org/10.4186/ej.2018.22.5.67

[33] Ardita, I. N., and I. W. A. Subagia. "The application of condensate water as an additional cooling media intermittently in condenser of a split air conditioning." In Journal of Physics: Conference Series, vol. 953, no. 1, p. 012059. IOP Publishing, 2018. https://doi.org/10.1088/1742-6596/953/1/012059

[34] Ibrahim, Nasiru I., Abdulghani A. Al-Farayedhi, and P. Gandhidasan. "Experimental investigation of a vapor compression system with condenser air pre-cooling by condensate." Applied Thermal Engineering 110 (2017): 1255-1263. https://doi.org/10.1016/i.applthermaleng.2016.09.042

[35] Yang, Hua, Na Pei, Liansheng Liu, Man Fan, and Yue Qin. "Experimental study on the effect of condensate water on the performance of split air conditioning system." Energy Reports 7 (2021): 840-851. https://doi.org/10.1016/i.egyr.2021.01.037

[36] Aziz, A., A. Samri, R. I. Mainil, and A. K. Mainil. "Performance of air source air conditioning water heater using trombone coil dummy condenser with different diameter and pipe length." Journal of Mechanical Engineering and Sciences 14, no. 2 (2020): 6743-6752. https://doi.org/10.15282/jmes.14.2.2020.16.0528

[37] Aziz, A., I. Amri, and A. K. Mainil. "Effect of heat recovery water heater system on the performance of residential split air conditioner using hydrocarbon refrigerant (HCR22)." In IOP Conference Series: Materials Science and Engineering, vol. 237, no. 1, p. 012010. IOP Publishing, 2017. https://doi.org/10.1088/1757-899X/237/1/012010

[38] Aziz, Azridjal, Thalal, and Afdhal Kurniawan Mainil. "Effect of Cooling Load on the Performance of R22 Residential Split Air Conditioner when Retrofitted with Hydrocarbon Refrigerant (HCR22)." Journal of Advanced Research in Fluid Mechanics and Thermal Sciences 48, no. 1 (2018): 100-108.

[39] Aziz, Azridjal, Arya Bhima Satria, and Rahmat Iman Mainil. "Experimental study of split air conditioner with and without trombone coil condenser as air conditioning water heater." International Journal of Automotive and Mechanical Engineering 12 (2015): 3043-3057. https://doi.org/10.15282/ijame.12.2015.18.0253

[40] Aziz, Azridjal, Rahmat Iman Mainil, Afdhal Kurniawan Mainil, and Eko Saputra. "Experimental evaluation on the use of capillary tube and thermostatic expansion valve with heat recovery hot spot water heater in air source refrigeration system." In AIP Conference Proceedings, vol. 1788, no. 1, p. 030023. AIP Publishing LLC, 2017. https://doi.org/10.1063/1.4968276

[41] Chaktranond, Chainarong, and Peachrakha Doungsong. "An experimental evaluation of energy saving in a split-type air conditioner with evaporative cooling systems." International transaction Journal of Engineering Management and Applied Sciences and Technologies 1, no. 1 (2010): 9-18.

[42] Moffat, Robert J. "Describing the uncertainties in experimental results." Experimental Thermal and Fluid Science 1, no. 1 (1988): 3-17. https://doi.org/10.1016/0894-1777(88)90043-X

[43] International Atomic Energy Agency. "Measurement uncertainty: A practical guide for secondary standards dosimetry laboratories." IAEA-TECDOC-1585, Vienna (2008). 